\title{
ASSESSING THE SKILLS AND COMPETENCIES AMONG PRINCIPALS IN TELECOMMUNICATION COMPANY LOCATED IN ILAM
}

\author{
Seidmehdi Veiseh ${ }^{1}$, Yasan allah Poorashraf ${ }^{2}$, Mohammad Taban $^{3}$ \\ ${ }^{1}$ Assistant Professor of Management Department, University of Ilam,Iran \\ Amir 7912000@yahoo.com \\ ${ }^{2}$ Associate Professor of Management Department, University of Ilam \\ yasan_ashraf@yahoo.com \\ ${ }^{3}$ Assistant Professor of Management Department, University of Ilam \\ taab1351@ut.ac.ir
}

\begin{abstract}
The main objective of the present study was to identify the required skills and competences for the managers of Telecom Company of the city of Ilam from the employee's perspective. The research method was descriptive-survey, and the participants were the staff of Ilam Telecom Company. 190 participants were selected randomly. The results of t-test and one the way ANOVA at the level of 0.05, and 95\% confidence level showed that there is no significant difference between academic discipline and cognitive skills. There was a significant difference between gender and the three skills. There is no significant difference between experience and conceptual skills. Management competence was obtained based on the t-test and analysis of variance of these results. There was significant difference between gender and level of the managerial competence. There was a significant difference between the field of the study and the level of the managerial competence. And finally, between level of education and level of the conceptual competence, there was no significant difference.
\end{abstract}

\section{KEYWORDS}

Skills, managerial skills, management competence, technical skills, conceptual skills, human skills

\section{INTRODUCTION}

Today, human resources are an organization's most important asset, so if the conditions for the exercise of managerial skills changes, the proper coordination should be made by the managers (Hammer \& champy, 2005). To achieve this, managers must take appropriate actions and coordination and put their training to the test. Usually managers are responsible for planning, organizing, leading, and controlling the various stages of an organization (shenhar \& Reiner, 2001). Managers are like people who are always on the hunt for opportunities to develop and enhance their knowledge, and to establish a strong relationship using their various skills. Drucker

David C. Wyld et al. (Eds) : CCSEA, CLOUD, DKMP, SEA, SIPRO - 2016

pp. 157-166, 2016. @ CS \& IT-CSCP 2016

DOI : $10.5121 /$ csit.2016.60214 
(2003 ) has argued that the challenges that occur in an organization are reflected in the implementation of effective and expansive changes, in this respect, the cooperation of managers paves the way for the position of an organization. This was conducted by the grounding of the character traits and skills of successful managers, and the methods of managing (Katzenbach \& smith, 2003). Another issue in this research is the concept of competence. Competencies are the axis of the heart of assessment and other elements are formed by them. Applying the term, competency, is a new approach that emerged in the 1970s, and developed and expanded in later years. The meaning of competence is the knowledge, abilities, skills, attitudes, and motivations for doing a successful work.

\section{Statement OF PROBLEM}

As mentioned above, management level, type and position of the organization, and demands placed on it are the major factors in skills, abilities, and competences required for managing. Consequently, with the knowledge of the effect of each of these three elements in needed combined skills, we can achieve educational needs and moving system of the manager in the management hierarchy. In recent centuries, the strong tendency for staff training has resulted in significance development of training in organizations and it has changed the opinion of the community about the missions and responsibilities of each organization completely. Today, the organizations have a more important role and the role of the managers is also more important because of the special role that each organization has in the developing the culture, society, and economy, it is more important than other occupations (Moayeri, 1998). The managers are under constant analysis because of the professional characteristics, assisting the difficult people (who are very resistant), non- voluntary clients and resolving tensions between employees. In most organizations, many problems are caused by the methods of management . Meanwhile, the good management of the organization depends on delegation and on the other hand, depends on the method used, managerial skills, and competence of managers. In categorizing the problems and the methods of using of skills and management competence by the managers are part of the operating issues in the management of the organizations. The majority of the managers of telecom organizations have relatively low technical skills and in some cases low human conceptual skills. Consequently, this research tries to study the skills and competencies required for managers of Ilam Telecom Company from the employees' point of view. So, this study seeks answer whether managers of Telecom Company have the required skills and competencies? And whether their management skills and competencies are different according to key demographic variables?

\section{HYPOTHESIS}

\subsection{General hypothesis:}

- Telecom Leaders possess desirable key skills and professional competence.

\subsection{Specific hypotheses:}

- Telecom managers possess desirable technical skills.

- Telecom managers possess desirable human skills

- Telecom managers possess desirable conceptual skills. 
- Managers possess desirable key competence (academic, managerial, conceptual, and moral competence).

\section{Certain Concepts}

Skills: the fosterable ability of a person that is reflected in performing and playing role and its main measure is performance and action in various conditions. (Alagheband, 2005)

Competence: describes a set of the behaviors that reflects a unique combination of knowledge, skills, abilities, and motivations and is associated with the performance in an organizational role (Viitala, 2005).

Managerial skills: management skills, a set of behaviors that leads to effective performance in a job.

Technical skills: the knowledge and ability to perform specific tasks that requires mastery of techniques and special tools, and practical competence in behavior and activities (Alagheband, 2005).

\section{METHODOLOGY}

The present study is a practical study with regard to its aim and a descriptive study with regard to the type of study. Evaluative studies are a form of scientific research that evaluate the effectiveness or practicality of changed programs (Saei, 2008). In this study, like a survey, the researcher uses questionnaire or interview to explore ideas, thoughts, perceptions and preferences of its intended people. Necessary data to test the research hypotheses were collected by a questionnaires given to a sample and was analyzed after filling the questionnaires.

- The participants

The participants of the present study were the entire staff of Ilam Telecom Company. It should be noted that in this study we only considered the employees that by the year 1392 had at least 3 years working experience. Thus, the study population consisted of 377 employees.

- Sampling method

In this study the simple random sampling was used. Random sampling is a method to choose a part of a society in a way that all the possible samples have an equal chance of being chosen (Khaki, 2011).

- The sample size

There are many methods and formulas to determine sample size. In this study, the sample size was calculated using Cochran formula. The number of cases per 377 was estimated 190 people. 


\section{THE ANALYSIS OF RESEARCH HYPOTHESIS}

Hypothesis 1: The attitude of both males and females is different regarding management skills.

To assess this hypothesis, the t-test was used for comparison of two groups of males and females. The findings are as follows.

Table 1. t-test to compare means between two groups

\begin{tabular}{|c|c|c|c|c|c|c|c|c|c|c|}
\hline \multicolumn{7}{|c|}{ T-test for equality of variances } & \multicolumn{2}{|c|}{$\begin{array}{l}\text { Leven test for } \\
\text { equality of } \\
\text { variances }\end{array}$} & & \\
\hline \multicolumn{2}{|c|}{$\begin{array}{c}\text { With } 95 \% \\
\text { difference } \\
\text { confidence } \\
\text { between } \\
\text { repeated t-test }\end{array}$} & \multirow[t]{2}{*}{$\begin{array}{l}\text { Standard } \\
\text { deviation }\end{array}$} & \multirow[t]{2}{*}{$\begin{array}{l}\text { Devia } \\
\text { tion } \\
\text { from } \\
\text { the } \\
\text { mean }\end{array}$} & \multirow[t]{2}{*}{$\begin{array}{c}\text { Signifi } \\
\text { cance } \\
\text { level }\end{array}$} & \multirow[t]{2}{*}{$\begin{array}{c}\text { Degrees } \\
\text { of } \\
\text { freedom }\end{array}$} & \multirow[t]{2}{*}{$\mathbf{t}$} & \multirow[t]{2}{*}{ Sig. } & \multirow[t]{2}{*}{$\mathbf{F}$} & & \\
\hline most & least & & & & & & & & & \\
\hline 0.000 & -0.108 & 0.028 & -0.054 & 0.042 & 188 & $\begin{array}{c}2.94 \\
-\end{array}$ & \multirow{2}{*}{0.039} & \multirow{2}{*}{0.711} & $\begin{array}{r}\text { Assuming } \\
\text { equal } \\
\text { variances }\end{array}$ & \multirow{2}{*}{$\begin{array}{c}\text { Comm } \\
\text { unicati } \\
\text { ve } \\
\text { skills }\end{array}$} \\
\hline 0.000 & -0.108 & .0 .028 & -0.054 & 0.041 & 187.7 & $\begin{array}{c}2.95 \\
-\end{array}$ & & & $\begin{array}{c}\text { Assuming } \\
\text { inequality - } \\
\text { Variance }\end{array}$ & \\
\hline 0.020 & -0.076 & 0.025 & -0.028 & 0.025 & 188 & $\begin{array}{c}3.14 \\
-\end{array}$ & \multirow{2}{*}{0.029} & \multirow{2}{*}{1.101} & $\begin{array}{r}\text { Assuming } \\
\text { equal } \\
\text { variances }\end{array}$ & \multirow[t]{2}{*}{$\begin{array}{c}\text { Techni } \\
\text { cal } \\
\text { skills }\end{array}$} \\
\hline 0.020 & -0.076 & 0.025 & 0.028 & 0.023 & 187.7 & $\begin{array}{c}3.15 \\
-\end{array}$ & & & $\begin{array}{c}\text { Assuming } \\
\text { inequality - } \\
\text { Variance }\end{array}$ & \\
\hline 0.085 & 0.011 & 0.019 & 0.048 & 0.017 & 188 & 2.57 & \multirow[t]{2}{*}{0.024} & \multirow[t]{2}{*}{5.089} & $\begin{array}{r}\text { Assuming } \\
\text { equal } \\
\text { variances }\end{array}$ & \multirow[t]{2}{*}{$\begin{array}{c}\text { Human } \\
\text { skills }\end{array}$} \\
\hline 0.085 & 0.011 & 0.019 & 0.048 & 0.014 & 187.7 & 2.57 & & & $\begin{array}{l}\text { Assuming } \\
\text { inequality }\end{array}$ & \\
\hline
\end{tabular}

the formulation of hypothesis $\checkmark$

$\{\mathrm{H} 0: \mu 1=\mu 2 \checkmark$

H1: $\mu 1 \neq \mu 2 \quad \checkmark$

calculation of $\mathrm{t}:=2.57-3.14, \mathrm{t} 3=\mathrm{t} 1=-2.94, \mathrm{t} 2$

Determining the degrees of freedom: $\mathrm{df}=188$

$\mathrm{T}$ Extractor table with degrees of freedom 188, $\mathrm{t}=1.96$

$\mathrm{T}$ table $>$ the calculated $\mathrm{t}$ and Comparison and Conclusion: for the three skills

Based on the Leven test, the significance level was less than 0.05 for all three types of skills $(\mathrm{Sig} 1=0.03, \mathrm{Sig} 2=0.029, \mathrm{Sig} 3=0.024)$, therefore we used the results which did not assume equal variances. Since the Leven test significance level is less than 0.05 , we applied the second test, t-test for two independent groups.

As presented in the above table, the calculated t value of 2.94 was obtained for conceptual skills (of course, taking the absolute value of $t$ ), on the other hand, the value of t table with degrees of 
freedom of 188 is equal to 1.96 , therefore because the calculated $t$ is greater than $t$ table, we can claim that in the confidence level of 0.05 there is a significant difference between the attitudes of male and female employees, regarding the communicating skills of managers. On the other hand, Sig is lower than 0.05 , so we can confirm the hypothesis with $95 \%$ confidence.

$\mathrm{T}$ value of 3.14 was calculated for technical skills (of course, taking the absolute value of $\mathrm{t}$ ), on the other hand, the value of $t$ table with degrees of freedom of 188 is equal to 1.96 , therefore because the calculated $t$ is greater than $t$ table, we can claim that in the confidence level of 0.05 there is significant difference between the attitudes of male and female employees, regarding the technical skills of managers. On the other hand, Sig is lower than 0.05 , so we can confirm the hypothesis with $95 \%$ confidence.

T value of 2.57 was calculated for human skills (of course, taking the absolute value of $t$ ), on the other hand, the value of $t$ table with degrees of freedom of 188 is equal to 1.96 , therefore because the calculated $t$ is greater than $t$ table, we can claim that in the confidence level of 0.05 there is significant difference between the attitudes of male and female employees, regarding the technical skills of managers. On the other hand, Sig is lower than 0.05 , so we can confirm the hypothesis with $95 \%$ confidence.

The second hypothesis: the views of people according to their field of study are different about the managerial skills of the managers.

Table 2. the independent $t$-test to compare the means of two groups of managerial and non-managerial

\begin{tabular}{|c|c|c|c|c|c|c|c|c|c|c|}
\hline & & est for $e$ & uality 0 & varianc & & & $\begin{array}{r}\text { Lever } \\
\text { equ } \\
\text { var }\end{array}$ & $\begin{array}{l}\text { est for } \\
\text { ity of } \\
\text { nces }\end{array}$ & & \\
\hline $\begin{array}{r}\text { Wit } \\
\text { diff } \\
\text { con } \\
\text { be } \\
\text { repea }\end{array}$ & $\begin{array}{l}95 \% \\
\text { ence } \\
\text { lence } \\
\text { een } \\
\text { d t-test }\end{array}$ & $\begin{array}{l}\text { Stand } \\
\text { ard } \\
\text { deviat } \\
\text { ion }\end{array}$ & $\begin{array}{c}\text { Deviat } \\
\text { ion } \\
\text { from } \\
\text { the }\end{array}$ & $\begin{array}{l}\text { Signifi } \\
\text { cance } \\
\text { level }\end{array}$ & $\begin{array}{l}\text { Degre } \\
\text { es of } \\
\text { freed } \\
\text { om }\end{array}$ & $t$ & Sig. & F & & \\
\hline most & least & & & & & & & & & \\
\hline 0.122 & -0.029 & 0.038 & 0.046 & 0.130 & 188 & 1.202 & & & $\begin{array}{r}\text { Assuming equal } \\
\text { variances }\end{array}$ & $\begin{array}{l}\text { Communicativ } \\
\text { e skills }\end{array}$ \\
\hline 0.199 & -0.027 & 0.037 & 0.046 & 0.120 & 187.3 & 1.246 & 0.023 & 0.327 & $\begin{array}{c}\text { Assuming } \\
\text { inequality - } \\
\text { Variance }\end{array}$ & \\
\hline 0.152 & 0.018 & 0.034 & 0.085 & 0.012 & 188 & 2.50 & & & $\begin{array}{r}\text { Assuming equal } \\
\text { variances }\end{array}$ & $\begin{array}{l}\text { Technical } \\
\text { skills }\end{array}$ \\
\hline 0.157 & 0.013 & 0.034 & 0.085 & 0.021 & 187.3 & 2.344 & 0.032 & 3.699 & $\begin{array}{c}\text { Assuming } \\
\text { inequality - } \\
\text { Variance }\end{array}$ & \\
\hline 0.021 & -0.081 & 0.026 & -0.035 & 0.243 & 188 & -1.15 & 0040 & 0028 & $\begin{array}{r}\text { Assuming equal } \\
\text { variances }\end{array}$ & Human skills \\
\hline 0.024 & -0.083 & 0.027 & -0.035 & 0.243 & 187.3 & -1.10 & 0.040 & 0.028 & $\begin{array}{c}\text { Assuming } \\
\text { inequality }\end{array}$ & \\
\hline
\end{tabular}

\footnotetext{
the formulation of hypothesis

$\{\mathrm{H} 0: \mu 1=\mu 2$

$\{\mathrm{H} 1: \mu 1=\mu 2$
} 
Calculating the value of $\mathrm{t}:=-1.152 .50, \mathrm{t} 3=\mathrm{t} 1=1.202, \mathrm{t} 2$

Determining the degree of freedom: $\mathrm{df}=188$

$\mathrm{T}$ Extractor table with degrees of freedom 188, $\mathrm{t}=1.96$

Comparison and conclusion: for the technical skill the calculated $t$ is $>t$ table and for the other two skills the relation is reversed.

Based on the Leven test, the significance level was less than 0.05 for all three types of skills $\left(\mathrm{Sig}_{1}=0.023, \mathrm{Sig}_{2}=0.032, \mathrm{Sig}_{3}=0.040\right)$, therefore we used the results which did not assume equal variances. Since the Leven test significance level is less than 0.05 , we applied the second test, ttest for two independent groups.

As presented in the above table, the calculated t value of 202.1 was obtained for conceptual skills (of course, taking the absolute value of $t$ ), on the other hand, the value of $t$ table with degrees of freedom of 188 is equal to 1.96 , therefore because the calculated $t$ is greater than $t$ table, we can claim that in the confidence level of 0.05 there is no significant difference between the attitudes of employees, regarding the communicating skills of managers. On the other hand, Sig is higher than 0.05 , so we can reject the hypothesis with $95 \%$ confidence.

$\mathrm{T}$ value of 50.2 was calculated for technical skills, on the other hand, the value of table with degrees of freedom of 188 is equal to 1.96 , therefore because the calculated $t$ is greater than $t$ table, we can claim that in the confidence level of 0.05 that regarding the employees' point of view there is significant difference between the technical skills of managers and their field of study.

$\mathrm{T}$ value of - 15.1 was calculated for human skills, on the other hand, the value of $\mathrm{t}$ table with degrees of freedom of 188 is equal to 1.96 , therefore because the calculated $t$ is greater than $t$ table, we can claim that in the confidence level of 0.05 regarding the employees' point of view there is significant difference between the human skills of managers and their field of study. On the other hand, Sig is higher than 0.05 , so we can reject the hypothesis with $95 \%$ level of confidence.

The third hypothesis: The view of staff is different about the level of management skills of managers according to their level of education

Table 3. One-way analysis of variance

\begin{tabular}{|l|l|l|l|l|l|l|}
\hline Sig. & $\begin{array}{l}\text { F } \\
\text { value }\end{array}$ & $\begin{array}{l}\text { Mean } \\
\text { square }\end{array}$ & $\begin{array}{l}\text { Degrees } \\
\text { of } \\
\text { freedo } \\
\mathbf{m}\end{array}$ & $\begin{array}{l}\text { Sum of } \\
\text { squares }\end{array}$ & Source of change & $\begin{array}{l}\text { Variables of the } \\
\text { research }\end{array}$ \\
\hline 0.045 & 2.69 & 0.355 & 3 & 1.064 & Between-group differences & $\begin{array}{l}\text { Communicative } \\
\text { skills }\end{array}$ \\
\cline { 3 - 6 } & & 0.132 & 186 & 90.73 & Intra-group differences & \\
\cline { 3 - 6 } & & - & 189 & 91.73 & total & \multirow{2}{*}{ Technical skills } \\
\hline 0.029 & 3.032 & 0.312 & 3 & 0.937 & Between-group differences \\
\cline { 3 - 6 } & & 0.103 & 186 & 70.86 & Intra-group differences & \\
\cline { 3 - 6 } & & & & & &
\end{tabular}




\begin{tabular}{|l|l|l|l|l|l|l|}
\hline & & - & 189 & 71.80 & total & \\
\hline \multirow{2}{*}{0.135} & \multirow{2}{*}{1.86} & 0.113 & 3 & 0.339 & Between-group differences & \multirow{2}{*}{ Human skills } \\
\cline { 3 - 5 } & & & & & & \\
\cline { 3 - 6 } & & 0.061 & 186 & 41.84 & Intra-group differences & \\
\cline { 3 - 5 } & & - & 189 & 42.08 & total & \multicolumn{2}{|l}{} \\
\hline
\end{tabular}

the formulation of hypothesis

$\mathrm{H} 0: \mu_{1-} \mu_{2-} \mu_{3-} \mu_{4}$

$\{\mathrm{H} 1: \mu 1+\mu 2+\mu 3+\mu 4$

Calculation of $\mathrm{f}$ value $:=1.863 .032, \mathrm{f} 3=\mathrm{f} 1=2.69, \mathrm{f} 2$

Determining the degree of freedom: the row degree of freedom 3 and column 186

extraction from Table f: $\mathrm{F}(\mathrm{df}: 3,186 \& \mathrm{p}=0.05)=2.62$

comparison: $\underline{\mathrm{f} 3<\mathrm{fj}}, \mathrm{f} 2>\mathrm{fj}, \mathrm{f} 1>\mathrm{fj}$

Conclusion: As presented in the above table, because the calculated $\mathrm{f}$ value for technical and conceptual skills was higher than $\mathrm{f}$ table, so we can claim that with the confidence level of $\% 95$ that there is a significant difference between the means of educational groups regarding the technical and conceptual skills. On the other hand, Sig for the two skills was lower than 0.05, $\left(\mathrm{Sig}_{1}=0.045, \mathrm{Sig}_{2}=0.029\right)$, so again, with the level of $95 \%$ confidence we can claim that there is significant difference between the educational groups regarding the assessing the technical and conceptual skills of managers.

Regarding the human skills, because the calculated $\mathrm{f}$ is lower than the $\mathrm{f}$ table, we can claim with the level of confidence of $\% 95$ that there is no significant difference between means of the educational groups regarding the assessing the human skills of managers. On the other hand, as the table shows Sig. is higher than 0.05. So, again with the level of confidence of $\% 95$ we can claim that there is no significant difference between the level of education of the employees regarding the assessing the human skills of the managers.

The structure graph of differences which is about the comparison of means suggests that where differences may occur. As the structure graph of differences indicates when the degree is higher than Bachelor, the difference between the various types of skill becomes greater.

The fourth hypothesis: Based on experience, perceptions of the staff about management skills differs.

Table 6-4. One-way analysis of variance

\begin{tabular}{|l|l|l|l|l|l|l|}
\hline Sig. & F value & $\begin{array}{l}\text { Mean } \\
\text { square }\end{array}$ & $\begin{array}{l}\text { Degrees } \\
\text { of } \\
\text { freedom }\end{array}$ & $\begin{array}{l}\text { Sum of } \\
\text { squares }\end{array}$ & Source of change & $\begin{array}{l}\text { Variables of the } \\
\text { research }\end{array}$ \\
\hline 0.102 & 1.93 & 0.25 & 4 & 1.02 & $\begin{array}{l}\text { Between-group } \\
\text { differences }\end{array}$ & $\begin{array}{l}\text { Communicative } \\
\text { skills }\end{array}$ \\
\cline { 3 - 5 } & 0.13 & 185 & 90.77 & $\begin{array}{l}\text { Intra-group } \\
\text { differences }\end{array}$ & \\
\hline
\end{tabular}




\begin{tabular}{|l|c|c|c|c|l|l|}
\hline & & - & 189 & 91.79 & total & \\
\hline 0.001 & 4.80 & 0.48 & 4 & 1.95 & $\begin{array}{l}\text { Between-group } \\
\text { differences }\end{array}$ & \multirow{2}{*}{ Technical skills } \\
\cline { 3 - 6 } & & 0.10 & 185 & 69.85 & $\begin{array}{l}\text { Intra-group } \\
\text { differences }\end{array}$ & \\
\cline { 3 - 6 } & & - & 189 & 71.80 & total & \\
\hline 0.004 & 3.84 & 0.23 & 4 & 0.92 & $\begin{array}{l}\text { Between-group } \\
\text { differences }\end{array}$ & \multirow{2}{*}{ Human skills } \\
\cline { 3 - 6 } & & 0.06 & 185 & 41.16 & $\begin{array}{l}\text { Intra-group } \\
\text { differences }\end{array}$ & \\
\cline { 3 - 6 } & & - & 189 & 42.08 & total & \\
\cline { 3 - 6 } & & & & & & \\
\hline
\end{tabular}

the formulation of hypothesis

$\mathrm{H} 0: \mu_{1-} \mu_{2-} \mu_{3-} \mu_{4} \mu_{5}$

$\left\{\mathrm{H} 1: \mu 1, \mu 2+\mu^{3} \div \mu 4 \div \mu_{6}\right.$

Calculation of $\mathrm{f}$ value $:=3.8404 .804, \mathrm{f} 3=\mathrm{f} 1=1.939, \mathrm{f} 2$

Determining the degree of freedom: the row degree of freedom 4 and column 185

Extraction from Table f: $F_{\text {(df } 4,185 \& p-005)-2.39}$

comparison: $\underline{\mathrm{f} 3>\mathrm{fi}}, \mathrm{f} 2>\mathrm{fj}, \mathrm{f} 1<\mathrm{fj}$

Extraction of conclusion: As presented in the above table, because the calculated $\mathrm{f}$ value for technical and conceptual skills was higher than $f$ table, so we can claim that with the confidence level of $\% 95$ that there is a significant difference between the means of years of experience regarding the technical and conceptual skills of the mangers. On the other hand, Sig for the two skills was lower than 0.05, (Sig3 $=0.004$, Sig2 $=0.001)$, so again, with the level of $95 \%$ confidence we can claim that there is a significant difference between the years of experience regarding the assessing the technical and conceptual skills of managers.

Regarding the conceptual skills, because the calculated $\mathrm{f}$ is lower than $\mathrm{f}$ table, we can claim that with the confidence level of $\% 95$ there is a significant difference between the means of years of experience regarding the conceptual skills of the mangers. On the other hand, as presented in the table Sig for the two skills was higher than 0.05 . So again, with the level of $95 \%$ confidence we can claim that there is no significant difference between the years of experience regarding the assessing the technical and conceptual skills of managers.

The structure graph of differences which is about the comparison of means suggests that where differences may occur. As the structure graph of differences indicates the higher the years of experience, the better the staffs' assessment is about technical and human skills of the managers. Difference between the various types of skill becomes greater. The structure graph of differences is as follows. And conceptual skills has decreased-increased changes

\section{SUMMARY AND CONCLUSIONS RESULTING FROM THE EXAMINATION AND TESTING THE RESEARCH QUESTIONS AND HYPOTHESES}

First research question: How much the managers possess the managerial skills of a manager? 
Results showed that technical skills had the highest score (mean 3.61, SD 0.32) and conceptual skills had the lowest score (mean 3.37, SD 0.364). So, considering the obtained results, it can be concluded that most of the staff believe that managers have high technical skills and low conceptual skills. This result is consistent with the research of Mojtaba Hosseini Nia (2007). From the results of his study, he concluded that technical skills are the most important factor in an organization's effectiveness. This factor is evaluated in his study at a high level.

The above results are consistence with the study of Johnson (2000), in his opinion the important factor in the effectiveness of manager on managing the staff is his area of expertise and skill (technical skills).

Research Question 2: How much the managers possess managerial competence?

The results showed that the subjects of the study in case of their competence, academic competence had the mean of 3.48 and SD of 0.375 which was the lowest mean. And the moral competence with the mean of 3.55 and SD of 0.351 had the highest mean. So, as the data presented in the aforesaid table shows, it can be concluded that in the opinion of the employees, the managers of the Ilam Telecom Company have high moral competence and low academic competence. The categorization of the competencies from the highest to the lowest competence is as follows.

Moral competence > Managerial Competence > Conceptual Competence > Academic competence

To conclusion of the current study is in line with the research of Ahmadi (2003), in his study there was a significant relationship between gender and the level of human skills, conceptual and technical.

The results of the foresaid question was consistent with Rabbani's research results (1380), he concluded that there is a significant relationship between gender and the three competencies.

The third hypothesis of the research: is there a significant relation between the academic field of the study of the staff and their assessment of the managers' managerial skills?

The findings showed that a significant level of 0.05 and the confidence level of 95\%:

- There is no significant relationship between the academic field of study and the conceptual and human skill.

There is a significant relation between the academic field of study and technical skills.

The result of this study is the same as the research results of Mir sadooghi (2006). In his study he found that the assessment of the human skill of the managers by the staff is not different based on whether they have a management degree or not. And statistically there is no significant relation between the two groups. However, the mean of the human skills of the managers with a degree other than management was higher than the managers who had a degree in management.

The fourth hypothesis of the study: is there significant relation between the academic level of employees and their assessment of the three managerial skills? 
The results showed that in a significant level of 0.05 and the confidence level of $95 \%$ there is a significant difference between the technical and conceptual skills, but this is not true for human skills.

The above hypothesis regarding the human skill was in line with the research of Sheikhzadeh(2008), he believed that there is no significant relation between the level of education and the level of possessing the human skills. The results of the hypothesis regarding the human skills contrasts the results of Pezeshk (1999), but regarding the two other skills the results is the same.

\section{REFERENCES}

[1] Ahmadi , A. ( 2003). The rate of secondary school principals in the city Kamyaranplainis skills (technical, human and conceptual) and their relationship with the effectiveness of teachers' views of the school year 2002-2003, MS Thesis martyr Beheshti University in Educational Administration

[2] AlagheBand, A.(2005).Public Management(Second Edition),Tehran, publishmental.

[3] Drucker, P. (2003). No son empleados, son personas (Thay are not employees, thy are people), Trend management, 4 (4): 16-22.

[4] Hammer, J \& champ, R .(2005). Skill of effective administration,Harvard business review,vol

[5] Hosseini -Nia , M. ( 2007). The survey of executives modernization, development and equipping of schools from Triple Management Skills (technical, human, conceptual) looking at the impact on employees and their effectiveness, Tehran, master's thesis martyr Beheshti University in Educational Administration

[6] Johnson,S. (2000). The concept of Competency: An Operational Defination.Educational Technology, 18 (2).

[7] Khaki, G.(2011).Approachto theresearchdissertation.Tehran, publishingreflection

[8] Katzenbach, G \& smith, E. (2003). Principles of modern managerial skills.IIIinons peacock publisher Inc.

[9] Mo'ayyeri,M.T.(1998).Education issues, Eighth Edition,Tehran,Amir KabirPublications7-

[10] Myrsdvqhy , S.H, (2006 ). Study of human skills in Qazvin school administrators and their relationship with burnout, Journal of Knowledge Management, No. 3 , Summer 84.pp.132-149

[11] Pezeshk , A.S, (1999 ). City high school teachers opinions about the characteristics of cognitive, emotional, and functional requirements for effective managers in high school , "Master's Thesis in Educational Administration University

[12] Shenhar \& Reiner.(2001). Leadership Skill for manager, New york: By McGraw-Hill

[13] Viitala, R. (2005). Perceived development needs of managers compared to an integrated management competency model, Journal of Workplace Learning, 17 (7): 36-41.

[14] Sheikhzadeh , M. ( 2008). Comprehensive look at the managers' performance evaluation model , Tehran Electronic Journals research group wide strategy , first issue, Fall 86 